\title{
Enzymatic Programs for Broilers
}

\author{
José Otávio Berti Sorbara ${ }^{2}$, Alice Eiko Murakami ${ }^{*}$, Eliane Saiuri Nakage ${ }^{1}$, Francisco \\ Piracés $^{2}$, Alexandra Potença ${ }^{1}$ and Rafael Lachinski Holanda Guerra ${ }^{1}$ \\ ${ }^{1}$ Departamento de Zootecnia; Universidade Estadual de Maringá; Av. Colombo, 5790; 87020-900; Maringá - PR - \\ Brasil. ${ }^{2}$ DSM Nutritional Products; São Paulo - SP - Brasil
}

\begin{abstract}
Two trials were conducted on floor pens to evaluate the performance of broilers fed with diets contained different carbohydrases enzyme programs at different ages. Trial 1- The body weight gain (BWG) was affected by the Negative Control $(N C)$ treatment $(P<0.05)$. However, when the birds were fed with the NC diet + Amilase $(A M Y)+X i l a n a s e(X Y L)$, the BWG improved and reached the same level as the Positive Control (PC). Trial 2- The birds received enzymes supplementation in the total phase and others only in the grower phase.The ME reduction by $120 \mathrm{kcal} / \mathrm{kg}$ increased the feed conversion ratio $(F C R)(P<0.05)$ when compared to $P C$ and none of the enzyme programs was able to recover the performance. It can be concluded that it is possible to supplement with AMY during the role period of broiler chicken life or use an enzymatic program with AMY or AMY+XYL only in the grower phase.
\end{abstract}

Key words: broilers, carbohydrase, enzymes, amylase, xylanase

\section{INTRODUCTION}

The use of enzymes in poultry nutrition has been studied for many years, although there was a significant increase in the number of recent publications. In several reports, the objective was to assess the action of a single enzyme or an enzyme mixture on the lifetime performance of broilers (Cowieson et al., 2003. Cowieson and Adeola, 2005, Juanpere et al., 2005, Mushtaq et al., 2007, Olukosi et al., 2007). Broilers, however, present physiological differences according to their age, size of gastrointestinal tract, production of endogenous enzymes, feed ingestion capacity, factors that will affect the digestibility of feed ingredients (Nitsan et al., 1991; Almirall et al.,
1995; Uni et al., 1998; Geyra et al., 2001; Huang et al., 2005; Huang et al., 2006).

Data published by Leslie et al. (2007) suggested that there is a relationship between age and capacity of the digestive tract, which should be taken into account when enzymes are used in poultry diets. Cowieson et al. (2006) also found that enzymes have different actions in the development of broilers when the finisher phase is compared to the starter period. Another point to be taken into account are the non-starch polysaccharides (NSPs) and starch present in the feed when the starter and grower diets are compared, even when they are corn and soybean meal based. Besides having high starch levels, corn also has more than $5 \%$ of arabinoxylans

\footnotetext{
* Author for correspondence: aemurakami@uem.br
} 
(Choct, 2006). As corn is included at higher levels in the finisher diets for broilers, the ratio of these polysaccharides (starch and arabinoxylans) increase while other NSPs decrease when compared to the starter feed. No report on the use of different enzymes supplementing feed for the various broiler production stages was found. Thus, the objective of this study was to determine the possibility of using enzyme programs with different carbohydrases in corn and soybean meal based diets for broilers at different ages.

\section{MATERIALS AND METHODS}

All procedures were approved by the Ethics Committee on the use of animals in trials at the State University of Maringá (Report $n^{\circ} 031 / 2007$, Protocol 012/2007). Two trials with broiler chickens in floor pens were carried out in a conventional poultry house covered with ceramic roof tiles, closed by wire netting, movable curtains, and concrete floor. The rice hull litter was changed after each trial, and feed and water were available ad libitum.

Table 1- Carbohydrates composition (\%) of a starter and grower feed

\begin{tabular}{lccc}
\hline Carbohydrates & Starter Feed $^{\mathbf{1}^{2}}$ & Grower Feed $^{\mathbf{2}}$ & Grower: Starter Ratio \\
\hline Starch & 33.47 & 38.78 & 1.16 \\
Rhamnose & 0.167 & 0.128 & 0.77 \\
Fucose & 0.097 & 0.078 & 0.81 \\
Arabinose & 1.763 & 1.682 & 0.95 \\
Xylose & 1.811 & 2.038 & 1.13 \\
Mannose & 0.622 & 0.552 & 0.89 \\
Galactose & 1.692 & 1.406 & 0.831 \\
Glucose & 3.257 & 3.025 & 0.929 \\
Total NSPs & 0.167 & 0.128 & 0.767 \\
Uronic Acid & 9.41 & 8.734 & 0.928 \\
\hline
\end{tabular}

- Considering a starter feed composition of $56 \%$ corn and $36 \%$ soybean meal.

2 - Considering a grower feed composition of $64 \%$ corn and $29 \%$ soybean meal.

All feeds were based on corn and soybean meal and used as mashed feed. Samples of corn and soybean meal used in Trial 2 were submitted to the Novozymes Laboratory in Denmark to determine the non starch carbohydrates and starch composition of these ingredients. Based on these results, the carbohydrates composition was calculated for a starter feed (56\% corn and 36\% soybean meal) and a grower feed (64\% corn and $29 \%$ soybean meal) (Table 1). It was found that starch and xylose had a $18 \%$ and $15 \%$ increase, respectively, and all the other NSPs and free sugar decrease when the grower diet was compared to the starter diet, in agreement with the assumption previously stated.

All diets used in Trial 2 were supplemented with phytase enzyme (the nutritional matrix values for phytase were $0.1 \%$ available phosphorus, $0.1 \%$ $\mathrm{Ca}$, and $12 \mathrm{kcal} \mathrm{ME} / \mathrm{kg}$ ) and was not considered as part of the treatment.

The feeding program included a starter feed and a grower feed, and performance was measured when the starter feed was replaced by the grower feed and also at the end of the experimental period. Body Weight Gain (BWG), Feed Conversion
(FC), ratio between the total feed consumed and the sum of the birds live weight and the weight of the dead birds, Feed Intake (FI), and Body-weight Adjusted Feed Conversion (AFC) were measured in every stage and mortality was measured only at the end. The equations used to calculate AFC were based on Carvalho (2001) and the following formulas were used: in the starter phase, a $0.7 \mathrm{~kg}$ standard weight gain was used: $\mathrm{AFC}=(0.7-$ $\mathrm{WG})+\mathrm{FC}$; in the grower phase, a $1.8 \mathrm{~kg}$ standard weight gain was used: $\mathrm{AFC}=[(1.8-\mathrm{WG}) / 3.2]+\mathrm{FC}$; and for the total experimental period a $2.5 \mathrm{~kg}$ standard weight gain was used: $\mathrm{AFC}=[(2 . .5-$ WG)/3.7]+FC. The 3.2 and 3.7 values present in the grower and the total experimental period formulas, respectively, are the correction factors for the standard weight gain. The WG and FC used in the formulas are the WG and FC for each phase. AFC is very useful in the FC comparison when there are different WG, allowing the comparison between different treatments and different trials. The enzymes used in this trial were $\alpha$-amylase (AMY), xylanase (XYL) and $\beta$-glucanase (GLU) and they were supplied by DSM Nutritional Products - Holland. The products and doses used 
were 400 ppm Ronozyme ${ }^{\circledR}$ A (CT) (containing $\alpha$ amylase and endo 1,3:1,4- $\beta$-glucanases); $100 \mathrm{ppm}$ Ronozyme $^{\circledR} \quad$ WX (CT) (containing endo-1,4xylanase); and 360 ppm Ronozyme ${ }^{\circledR}$ VP (CT) (containing endo-1,3(4)- $\beta$-glucanase, pentosanase, hemicellulase and pectic-substance hydrolyzing activities), respectively. The doses that were used were based on the manufacturer's commercial recommendations and according to Vieira et al. (2007).

Trial 1 - Performance from 21 to 40 days of age This trial was carried out to determine the possibility of using one or two enzymes only after the birds were 21 days of age.

A total of 680 male Cobb Vantress ${ }^{\circledR}$ - USA chicks was used in a fully randomized design, with four treatments and five replicates, 34 birds each. The birds were raised from 1 to 20 days of age under the same environmental conditions, and the starter feed was not supplemented with any exogenous enzyme. The following treatments were used: positive control (PC) with adequate nutritional levels, negative control (NC) with adequate nutritional levels except for metabolizable energy, which was reduced by $120 \mathrm{kcal} \mathrm{ME} / \mathrm{kg}$ feed when compared to PC. The same feed used in the NC treatment was supplemented with AMY in third treatment and with AMY+XYL in fourth treatment. The composition and nutrients supplied by the feed in treatments PC and NC are presented in Table 2.

Table 2 - Grower feed composition used in Trial 1 (g/kg, as fed basis).

\begin{tabular}{|c|c|c|}
\hline Ingredients & Positive Control & Negative Control \\
\hline Corn & 640.02 & 666.24 \\
\hline Soybean meal & 283.03 & 278.28 \\
\hline Soybean oil & 37.71 & 16.18 \\
\hline Salt & 3.50 & 3.50 \\
\hline Sodium bicarbonate & 1.03 & 1.02 \\
\hline Limestone & 11.09 & 11.15 \\
\hline Dicalcium phosphate & 16.54 & 16.46 \\
\hline L-Lysine $\mathrm{HCl}$ & 2.04 & 2.13 \\
\hline DL-Methionine & 2.50 & 2.48 \\
\hline L-Threonine & 0.54 & 0.56 \\
\hline Mineral and Vitamin Premix ${ }^{1}$ & 1.50 & 1.50 \\
\hline Inert $^{2}$ & 0.500 & 0.50 \\
\hline \multicolumn{3}{|l|}{ Calculate nutritive value } \\
\hline $\mathrm{CP}(\%)$ & 18.50 & 18.50 \\
\hline $\operatorname{AME}(\mathrm{kcal} / \mathrm{kg})$ & 3,150 & 3,030 \\
\hline Dig. Lys (\%) & 1.04 & 1.04 \\
\hline Dig. Met+Cys (\%) & 0.77 & 0.77 \\
\hline Dig. Thr $(\%)$ & 0.66 & 0.66 \\
\hline $\mathrm{Ca}(\%)$ & 0.90 & 0.90 \\
\hline Av. P (\%) & 0.42 & 0.42 \\
\hline $\mathrm{Na}(\%)$ & 0.18 & 0.18 \\
\hline
\end{tabular}


Trial 2 - Performance from 1 to 40 days of age, with the use of amylase "on top" during the starter phase

This trial assessed the response to the enzyme used "on top" (that is, when the enzyme was used in a feed without reducing energy or any other nutrient) in the starter phase of the positive control
(PC) or when used "on top" in the grower phase of PC or was supplemented to the negative control (NC), formulated to be nutritionally marginal in relation to energy (ME $120 \mathrm{kcal} / \mathrm{kg}$ less than PC). The composition and nutrients supplied by the feed in treatments PC and NC are presented in Table 3.

Table 3 - Starter feed composition of the positive control treatment and grower feed composition of the positive and negative control treatments used in Trial 2 (g/kg, as-fed basis).

\begin{tabular}{|c|c|c|c|}
\hline \multirow{3}{*}{ Ingredients } & \multicolumn{3}{|c|}{ Phases } \\
\hline & \multirow{2}{*}{$\begin{array}{c}\text { Starter } \\
\text { Positive Control }\end{array}$} & \multicolumn{2}{|c|}{ Grower } \\
\hline & & Positive Control & Negative Control \\
\hline Corn & 584.45 & 648.83 & 675.84 \\
\hline Soybean meal & 353.00 & 281.00 & 276.00 \\
\hline Soybean oil & 25.00 & 34.00 & 12.00 \\
\hline Limestone & 13.00 & 12.00 & 12.00 \\
\hline Dicalcium phosphate & 12.30 & 11.10 & 11.00 \\
\hline Salt & 4.00 & 3.50 & 3.50 \\
\hline Sodium bicarbonate & 1.10 & 1.00 & 1.00 \\
\hline L-Lysine $\mathrm{HCl}$ & 1.02 & 2.08 & 2.17 \\
\hline DL-Methionine & 2.64 & 2.49 & 2.47 \\
\hline L-Threonine & 0.29 & 0.55 & 0.57 \\
\hline Choline Chloride $60 \%$ & 0.90 & 0.80 & 0.80 \\
\hline Coban $400^{1}$ & 0.30 & & \\
\hline Coxistac $12 \%^{2}$ & & 0.55 & 0.55 \\
\hline Starter Min/Vitamin Premix ${ }^{3}$ & 1.50 & & \\
\hline Grower Min/Vitamin Premix ${ }^{4}$ & & 1.50 & 1.50 \\
\hline Ronozyme P $5000(\mathrm{CT})^{5}$ & 0.10 & 0.10 & 0.10 \\
\hline $\begin{array}{l}\text { Inert }^{6} \\
\text { Calculate nutritive value }\end{array}$ & 0.40 & 0.50 & 0.50 \\
\hline $\mathrm{CP}(\%)$ & 21.50 & 18.50 & 18.50 \\
\hline AME (kcal/kg) & 2,980 & 3,150 & 3,030 \\
\hline Dig. Lys (\%) & 1.15 & 1.04 & 1.04 \\
\hline Dig. Met+Cys (\%) & 0.86 & 0.77 & 0.77 \\
\hline Dig. Thr (\%) & 0.75 & 0.66 & 0.66 \\
\hline $\mathrm{Ca}(\%)$ & 1.00 & 0.90 & 0.90 \\
\hline Av. P $(\%)$ & 0.45 & 0.42 & 0.42 \\
\hline $\mathrm{Na}(\%)$ & 0.20 & 0.18 & 0.18 \\
\hline
\end{tabular}

${ }^{\mathrm{T}}$ Monensin sodium $40 \%$

${ }^{2}$ Salinomycin $12 \%$

${ }^{3}$ Starter Mineral and Vitamin Premix providing per kg feed: 9,000 IU Vitamin A (all-trans retinol); 3,000 IU Vitamin $\mathrm{D}_{3}$

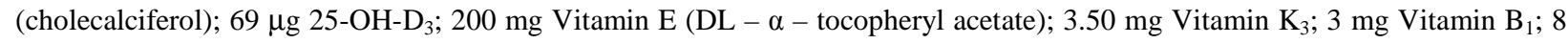
mg Vitamin $\mathrm{B}_{2} ; 6 \mathrm{mg}$ Vitamin $\mathrm{B}_{6} ; 40 \mu \mathrm{g}$ Vitamin $\mathrm{B}_{12} ; 50 \mathrm{mg}$ Niacin; $15 \mathrm{mg}$ Pantothenic Acid; $200 \mu \mathrm{g}$ Biotin; $1.50 \mathrm{mg}$ Folic Acid; $50 \mathrm{mg} \mathrm{Fe} ; 10 \mathrm{mg} \mathrm{Cu} ; 50 \mathrm{mg} \mathrm{Zn;} 80 \mathrm{mg} \mathrm{Mn} ; 400 \mu \mathrm{g} \mathrm{Se} ; 1 \mathrm{mg} \mathrm{I} ; 1 \mathrm{mg} \mathrm{Co.}$

${ }^{4}$ Grower Mineral and Vitamin Premix providing per kg feed: same mineral and vitamin levels of the starter phase except Vitamin $\mathrm{E}(\mathrm{DL}-\alpha-$ tocopheryl acetate) $50 \mathrm{mg}$.

${ }^{5}$ Phytase $5000 \mathrm{FYT} / \mathrm{g}$

${ }^{6}$ The enzymes were supplemented by the inert substitution. 
A total of 2,304 male Cobb $^{\circledR}$ Vantress $^{\circledR}$ - USA chicks were used, in 64 floor pens in a fully randomized design. Two treatments were used from 1 to 21 days of age, with 32 replicates each with 36 birds each: a PC (without enzyme) and a PC+AMY. Eight treatments were used from 21 to 40 days of age, with eight replicates. Each treatment of the starter phase was further divided into four during the grower phase. The four treatments of the grower phase originated from the starter phase that did not include enzymes were: $\mathrm{PC}, \mathrm{NC}$ with $120 \mathrm{kcal}$ less than PC, NC+AMY; and $\mathrm{NC}+\mathrm{AMY}+\mathrm{XYL}$. The other four treatments in the grower phase originated from the starter phase with amylase supplementation were: $\mathrm{PC}+\mathrm{AMY}$; $\mathrm{PC}+\mathrm{AMY}+\mathrm{XYL} ; \mathrm{NC}+\mathrm{AMY} ; \mathrm{NC}+\mathrm{AMY}+\mathrm{XYL}$.
The performance results were submitted to variance analysis using the GLM procedure from SAS $^{\circledR}$ (SAS Institute, 1990) and averages were compared by the Tukey's test, at 5\% significance level.

\section{RESULTS AND DISCUSSION}

Table 4 described the broilers performance fed with different enzymes programs used in Trial 1. The use of enzymes only during the grower phase in a diet with $120 \mathrm{kcal} / \mathrm{kg}$ less than the control group improved the weight gain, especially in the group treated with AMY+XYL $(P<0.05)$ when compared to the negative control (NC).

Table 4 - Feed conversion ratio (FCR), body weight gain (BWG), feed intake (FI), and adjusted feed conversion (AFC) of broiler chickens fed with corn soy diet from 21 to 40 days of age (Trial 1).

\begin{tabular}{lcccc}
\multicolumn{1}{c}{ Treatments } & FCR & BWG & FI & AFC \\
\hline Positive Control $^{1}$ & $1.835 \pm 0.035$ & $1.556 \pm 0.050^{\mathrm{a}}$ & $2.855 \pm 0.099^{\mathrm{ab}}$ & $1.926 \pm 0.040$ \\
Negative Control (NC) $^{2}$ & $1.894 \pm 0.055$ & $1.444 \pm 0.055^{\mathrm{b}}$ & $2.733 \pm 0.057^{\mathrm{b}}$ & $2.021 \pm 0.070$ \\
$\mathrm{NC}^{\mathrm{a}} \mathrm{AMY}^{3}$ & $1.863 \pm 0.085$ & $1.522 \pm 0.028^{\mathrm{ab}}$ & $2.910 \pm 0.097^{\mathrm{a}}$ & $1.952 \pm 0.112$ \\
$\mathrm{NC}+\mathrm{AMY}^{\mathrm{abY}}{ }^{4}$ & $1.852 \pm 0.042$ & $1.601 \pm 0.029^{\mathrm{a}}$ & $2.964 \pm 0.088^{\mathrm{a}}$ & $1.930 \pm 0.043$ \\
$\mathrm{CV}(\%)$ & 3.05 & 2.95 & $3.02^{2}$ & 3.67 \\
$P$ & 0.3585 & 0.0003 & 0.0031 & 0.1350 \\
\hline
\end{tabular}

${ }^{1}$ Positive control (PC) with optimal apparent metabolizable energy (AME) level.

${ }^{2}$ Negative control (CN) with $120 \mathrm{kcal}$ AME/kg less than the PC.

${ }^{3} \mathrm{AMY}-\alpha$-amylase supplemented by $400 \mathrm{ppm}$ inclusion of Ronozyme A.

${ }^{4} \mathrm{XYL}$ - xylanase supplemented by $100 \mathrm{ppm}$ inclusion of Ronozyme WX.

${ }^{\mathrm{a}, \mathrm{b}}$ Values followed by different letter in the same column are significantly different by Tukey test $(P<0.05)$.

Feed intake was affected by the enzyme supplementation, as supplemented birds had a higher feed intake than the NC $(P<0.05)$.

FI were not modified by the treatments $(P>0.05)$. The use of enzymes during the grower phase can improve the birds digestive capacity. The result being a higher feed intake and, as a consequence, a higher weight gain. Jorgensen et al. (1990) concluded that genetic selection favored broilers with a better feed conversion (FC), excluding the birds that consumed more feed than their digestive capacity.

Therefore, when feeds supplemented with exogenous enzymes that improve the digestive capacity of poultry are used, broilers are able to increase their feed intake.

One of the reasons for the improved response when xylanase is used with amylase is that the starch is better used as a result of $\alpha$-amylase activity, and soluble and insoluble NSPs as arabinoxylans are also degraded in free sugar as arabinose and xylose (Choct et al., 2004).

The improvement in performance obtained by adding xylanase to amylase may also be due to an improvement in the digestibility of amino acids from the feed ingredients, as reported by Rutherfurd et al. (2007). Studying the effect of $\alpha$ amylase plus xylanase in broilers fed corn and soybean meal based diets, these authors found a significant improvement in the digestibility of all amino acids with the true ileal digestibility method.

The performance parameters in Trial 2 are shown in Tables 5 and 6. FC and BWG were not affected when the positive control with adequate AME was supplemented with AMY, but there was a $10 \mathrm{~g}$ increase $(P<0.05)$ in FI in the starter period, demonstrating that there is an increase in feed intake when the digestive capacity of broilers is improved. In this case, however, the higher feed 
intake did not result in an improved weight gain. Olukosi et al. (2007) did not find any improvement in the birds performance when they supplemented the corn and soybean meal feed with a mixture of xylanase, amylase, and protease at 21 days of age. Iji et al. (2003) did not find an effect on broilers performance when enzymes were supplemented in the starter period. Gracia et al. (2003), found an improved performance when a corn and soybean meal based diet given to broilers from 1 to 42 days of age was supplemented with $\alpha$-amylase. When broilers are fed a theoretically perfect diet it is unlikely that they will show improved results when an enzyme is used "on top", as the bird is already demonstrating its full potential and there is little room for improved performance.

Considering the whole period (1 to 40 days), only
FC and AFC were influenced $(P<0.05)$ by the treatments, and the FC of the PC was $3.5 \%$ better than NC (Table 6). The improvement with enzyme supplementation was not more than $1 \%$ for $\mathrm{FC}$ and $\mathrm{AFC}$, and $1.5 \%$ for $\mathrm{WG}$ when AMY was used as a supplement for the $\mathrm{NC}$ in the grower phase and for the $\mathrm{PC}$ in the starter phase $(P>0.05)$. The response was similar to that found when the $\mathrm{NC}$ was supplemented with AMY+XYL in the grower phase and with no AMY supplementation in the starter phase.

The average AFC in the grower phase of Trials 1 and 2 was 1.96 and 1.73 , respectively, and the enzymes response on the broilers performance was lower in Trial 2, probably due to the excellent performance the broilers had independently of the treatment.

Table 5 - Feed conversion ratio (FCR), body weight gain (BWG), and feed intake (FI), of broiler chickens fed with corn soy diet from 1 to 20 days of age (Trial 2).

\begin{tabular}{lccc}
\multicolumn{1}{c}{ Treatments } & FCR & FI & BWG \\
\hline Positive Control $(\mathrm{PC})^{1}$ & $1.277 \pm 0.015$ & $1.021 \pm 0.019^{\mathrm{b}}$ & $0.799 \pm 0.015$ \\
PC + AMY ${ }^{2}$ & $1.283 \pm 0.015$ & $1.031 \pm 0.022^{\mathrm{a}}$ & $0.805 \pm 0.015$ \\
CV $(\%)$ & 1.19 & 2.03 & 1.85 \\
$P$ & 0.1018 & 0.049 & 0.1117 \\
\hline
\end{tabular}

${ }^{1}$ Positive control (PC) with optimal apparent metabolizable energy (AME) level.. ${ }^{2}$ AMY $-\alpha$-amylase supplemented by 400 ppm inclusion of Ronozyme A. ${ }^{\mathrm{a}, \mathrm{b}}$ Values followed by different letter in the same column are significantly different by Tukey test $(P<0.05)$.

Table 6 - Feed conversion ratio (FCR), body weight gain (BWG), feed intake (FI), and adjusted feed conversion (AFC) of broiler chickens fed corn soy diet from 1 to 40 days of age (Trial 2)

\begin{tabular}{|c|c|c|c|c|c|}
\hline \multicolumn{2}{|c|}{ Treatments in each phase } & \multirow{2}{*}{ FCR } & \multirow{2}{*}{ BWG } & \multirow{2}{*}{ FI } & \multirow{2}{*}{ AFC } \\
\hline Starter & Grower & & & & \\
\hline $\begin{array}{l}\text { Positive Control } \\
(\mathrm{PC})^{1}\end{array}$ & PC & $1.574 \pm 0.027^{\mathrm{c}}$ & $2.689 \pm 0.083$ & $4.229 \pm 0.100$ & $1.523 \pm 0.045^{b c}$ \\
\hline $\mathrm{PC}$ & Negative Control (NC) ${ }^{4}$ & $1.630 \pm 0.012^{\mathrm{a}}$ & $2.656 \pm 0.083$ & $4.330 \pm 0.147$ & $1.588 \pm 0.023^{a}$ \\
\hline PC & $\mathrm{NC}+\mathrm{AMY}$ & $1.621 \pm 0.017^{\mathrm{ab}}$ & $2.669 \pm 0.052$ & $4.328 \pm 0.084$ & $1.576 \pm 0.025^{\mathrm{a}}$ \\
\hline $\mathrm{PC}$ & $\mathrm{NC}+\mathrm{AMY}+\mathrm{XYL}$ & $1.621 \pm 0.027^{\mathrm{ab}}$ & $2.696 \pm 0.073$ & $4.369 \pm 0.125$ & $1.568 \pm 0.036^{\mathrm{ab}}$ \\
\hline $\mathrm{PC}+\mathrm{AMY}^{2}$ & $\mathrm{PC}+\mathrm{AMY}$ & $1.587 \pm 0.028^{\mathrm{bc}}$ & $2.724 \pm 0.089$ & $4.319 \pm 0.082$ & $1.510 \pm 0.025^{\mathrm{c}}$ \\
\hline $\mathrm{PC}+\mathrm{AMY}$ & $\mathrm{PC}+\mathrm{AMY}+\mathrm{XYL}^{3}$ & $1.568 \pm 0.011^{\mathrm{c}}$ & $2.758 \pm 0.054$ & $4.324 \pm 0.068$ & $1.498 \pm 0.023^{\mathrm{c}}$ \\
\hline $\mathrm{PC}+\mathrm{AMY}$ & $\mathrm{NC}+\mathrm{AMY}$ & $1.615 \pm 0.027^{\mathrm{ab}}$ & $2.694 \pm 0.050$ & $4.351 \pm 0.134$ & $1.562 \pm 0.023^{a b}$ \\
\hline $\mathrm{PC}+\mathrm{AMY}$ & $\mathrm{NC}+\mathrm{AMY}+\mathrm{XYL}$ & $1.622 \pm 0.022^{\mathrm{a}}$ & $2.682 \pm 0.052$ & $4.350 \pm 0.110$ & $1.573 \pm 0.024^{\mathrm{ab}}$ \\
\hline $\mathrm{CV}$ & & 1.39 & 2.55 & 2.53 & 1.880 \\
\hline$P$ & & 0.0001 & 0.1199 & 0.3203 & 0.0001 \\
\hline
\end{tabular}

${ }^{1}$ Positive control (PC) with optimal AME level.

${ }^{2} \mathrm{AMY}-\alpha$-amylase supplemented by 400 ppm inclusion of Ronozyme A.

${ }^{3} \mathrm{XYL}$ - xylanase supplemented by 100 ppm inclusion of Ronozyme WX.

${ }^{4}$ Negative control (CN) with $120 \mathrm{kcal}$ AME/kg less than the PC.

${ }^{\mathrm{a}, \mathrm{b}, \mathrm{c}}$ Values followed by different letter in the same column are significantly different by Tukey test $(P<0.05)$. 


\section{CONCLUSION}

It can be concluded that it is possible to supplement corn and soybean meal based feeds with AMY during the role period of broiler chicken life or use an enzymatic program with AMY or AMY + XYL only in the grower phase, resulting in improved performance. The study of new enzyme programs, with different enzymes for the various phases, opens a new area in the study of enzymes in poultry nutrition where the enzyme specificity, substrate diversity, and animal physiology are all correlated.

\section{ACKNOWLEDGEMENT}

The authors thank DSM Nutritional Products for the financial support, and Dan Pettersson, from Novozymes, who carried out the determination of NSPs and starch in the ingredients that were used in this research. The financial resources for the conduction of this study were supported by the project BioAgroPar financed by FINEP, SETI/PR, and Fundação Araucária/PR; and by CNPq/Brazil.

\section{RESUMO}

Para avaliar o desempenho de frangos de corte alimentados com rações com diferentes programas de enzimas carboidrases, foram realizados dois experimentos. No experimento 1 as aves receberam suplementação de enzimas apenas na fase de crescimento foi observado redução no ganho de peso (GP) daqueles alimentados com a ração Controle Negativo $(\mathrm{CN})$ ou seja, ração com redução de $120 \mathrm{kcal} / \mathrm{kg}$. No entanto, quando os frangos receberam a ração $\mathrm{CN}+$ Amilase (AMI) + Xilanase (XIL) o GP foi semelhante encontrado no Controle Positivo (CP). No Experimento 2, algumas aves tiveram enzimas em todo período de criação e outras tiveram apenas na fase de crescimento. $\mathrm{O}$ tratamento $\mathrm{CN}$ apresentou pior conversão alimentar que o CP. Pode-se concluir que é possível suplementar com AMI todo o período de criação das aves ou utilizar um programa enzimático com AMI ou AMI + XIL somente na fase de crescimento, sem prejuízo ao desempenho das aves.

\section{REFERENCES}

Almirall, M. M.; Francesch, A. M.; Perez-Vendrell, J. B.; Esteve-Garcia, E. (1995), The differences in intestinal viscosity produced by barley and $\beta$ glucanase alter digest enzyme activities and ileal nutrient digestibilities more in broiler chicks then in cocks. Journal Nutrition, 125, 947-955

Carvalho, A. F. M. (2001), Manejo final e da retirada. Paper presented at Conf. Apinco Ciência Tecnologia, Campinas, SP. Facta

Choct, M., A.; Kocher, D. L. E.; Waters, D. P.; Ross, G. (2004), A comparison of three xylanases on nutritive value of two wheats for broiler chickens. British Journal Nutrition, 92, 53-61

Choct, M. A. (2006), Enzymes for the feed industry: past, present and future. World's Poultry Science Journal, 62, 5-15

Cowieson, A. J.; Adeola, O. (2005), Carbohydrases, protease, and phytase have an additive beneficial effect in nutritionally marginal diets for broiler chicks. Poultry Science, 84,1860-1867

Cowieson, A. J.; Acamovic, T.; Bedford, M. R. (2003), Supplementation of diets containing pea meal with exogenous enzymes: effects on weight gain, feed conversion, nutrient digestibility and gross morphology of the gastrointestinal tract pf growing broiler chicks. British Poultry Science, 44, 427-437

Cowieson, A. J.; Singh, D.N.; Adeola, O. (2006), Prediction of ingredient quality and the effect of a combination of xylanase, amylase, protease and phytase in the diets of broiler chicks. 1. Growth performance and digestible nutrient intake. British Poultry Science, 47; 477-489

Geyra, A.; Uni, Z.; Sklan, D. (2001), Enterocyte dynamics and mucosal development in the posthatch chick. Poultry Science, 80, 776-782

Gracia, M. L.; Araníbar, M. J.; Lázaro, R.; Medel, P.; Mateos, G. G. (2003), $\alpha$-Amylase supplementation of broiler diets based on corn. Poultry Science, 82, 436442

Huang, K. H., Ravindran,V.; Li, X.; Bryden, W. L. (2005), Influence of age on the apparent ileal aminoacid digestibility of feed ingredients for broiler chickens. British Poultry Science, 46, 236245

Huang, K. H.; Li, X.; Ravindran, V.; Bryden, W. L. (2006), Comparison of apparent ileal amino acid digestibility of feed ingredients measured with broilers, layers, and roosters. Poultry Science, 85, 625-634

Iji, P. A.; Khumalo, K.; Slippers, S.; Gous, R. M. (2003), Intestinal function and body growth of broiler chickens on diets based on maize dried at different temperatures and supplemented with microbial enzymes. Reproduction Nutrition Development, 43, $77-90$ 
Jorgensen, H., P. Sorensen and B. O. Eggum. (1990), Protein and energy metabolism in broiler chickens selected for either body weight gain or feed efficient. British Poultry Science, 31, 517-524

Juanpere, J., Pérez-Vendrell, A. M.; Angulo, E.; Brufau, J. (2005), Assessment of potential interaction between phytase and glycosidase enzyme supplementation on nutrient digestibility in broilers. Poultry Science, 84, 571-580

Leslie, M. A.; Moran Jr., E. T.; Bedford, M. R. (2007), The effect of phytase and glucanase on the ileal digestible energy of corn and soybean meal fed to broilers. Poultry Science, 86, 2350-2357

Mushtaq, T., Sarwar, M.; Ahmad, G.; Mirza, M. A.; Nawaz, H.; Haroon Mushtaq, M. M.; Noreen, U. (2007), Influence of canola meal-based diets supplemented with exogenous enzyme and digestible lysine on performance, digestibility, carcass, and immunity response of broiler chickens. Poulry Science, 86, 2144-2155

Nitsan, Z., Dunnington, E. A.; Siegel, P. B. (1991), Organ growth and digestive enzyme levels to fifteen days of age in lines of chicken differing in body weight. Poultry Science, 70, 2040-2048
Olukosi, O. A., Cowieson, A. J.; Adeola, O. (2007), Age-related influence of cocktail of xylanase, amylase, and protease or phytase individually or in combination in broilers. Poultry Science, 86, 77-86

Rutherfurd, S. M.; Chung, T. K.; Moughan, P. J. (2007), The effect of a commercial enzymes preparation on apparent metabolizable energy, the true ileal amino acid digestibility, and endogenous ileal lysine losses in broiler chickens. Poultry Science, 86, 665-672

SAS institute. (1990) SAS/STAT User's Guide. Version $6.4^{\text {th }}$ ed. SAS Institute Inc., Cary, NC

Uni, Z.; Ganot, S.; Sklan, D. (1998), Posthatch Development of Mucosal Function in the Broiler Small Intestine. Poultry Science, 77, 75-82.

Vieira, S. L., Freitas, D. M., Coneglian, J. L.; Pena, J. E. M.; Berres, J. (2007), Live performance evaluation of broilers fed all vegetable corn-soy diets supplemented with an Alpha Amylase - Beta Glucanase blend. Poultry Science, 86 (1), 399 